\title{
Efektivitas Penggunaan Word Category Terhadap Peningkatan Minat Belajar Kosakata Pada Mata Pelajaran Bahasa Inggris
}

\author{
Terasne $^{1}$, Dira Permana ${ }^{2}$, Tri Setianingsih ${ }^{2}$ \\ ${ }^{123}$ Fakultas Budaya, Manegment, dan Bisnis, UNDIKAMA, Indonesia \\ terasne@ikipmataram.ac.id ${ }^{1}$ dirapermana@ikipmataram.ac.id ${ }^{2}$ \\ trisetianingsih@ikipmataram.ac.id ${ }^{3}$
}

\begin{abstract}
The purpose of this study was to determine whether the use of Word Category was effective in increasing the interest and learning achievement of students' vocabulary in English subjects at SMPN 1 Praya Barat. This research was a pre-experimental research with one-group pre-test-post-test design. The population of this research was all students of class II of SMPN 1 Praya Barat which were divided into 3 classes. They were class II-1 consisting of 23 students, class II-2 consisted of 32 students, and class II-3 consisted of 20 students. The total population of this study was 74 students. In this case, researchers took one class as a sample that was class II-1 consisting of 23 students. The research sampling technique used cluster random sampling classes. The research instrument used in the collection of research data was a multiple choice test to measure student vocabulary learning outcomes consisting of 25 items with various variants of questions and questionnaires with an alternative scale of answer choices to measure student vocabulary interest. The results found that the answers: strongly agree given a score of 5, agree given a score of 4, a score given doubtful 3, disagree score given 2, and strongly disagree given a score in this case the questionnaire research as the main data using the description method involving description and data interpretation. Researchers use questionnaires to determine student motivation in reading. Results of the analysis of the data description of the scores of the mean pre-test and Post-test deviation of students were obtained by dividing the number of deviation scores by the number of students seen 194/23 =8,435. In this study, the sample of data was 23 students, so the level of freedom (df) used was 23-1 = 22. After calculating the data interpretation it was found that $t$ test $=9,467 \geq t$-table $=1,717$. From the above results, the researcher concludes that the word category technique has a significant effect on students' reading comprehension. Therefore, the Alternative Hypothesis was accepted and the Null Hypothesis was rejected
\end{abstract}

Keywords: Word Category, Vocabulary, Students' Interest.

\begin{abstract}
Abstrak. Tujuan penelitian ini adalah untuk mengetahui, apakah penggunaan Word Category efektif terhadap peningkatan minat dan prestasi belajar kosakata siswa pada mata pelajaran bahasa Inggris di SMPN 1 Praya Barat. Penelitian ini adalah penelitian pre-experimental dengan desain one-group pre test-pos-test. Populasi penelitian ini adalah seluruh siswa kelas II SMPN 1 Praya Barat yang dibagi menjadi 3 kelas mereka adalah kelas $\mathrm{II}^{-}{ }^{-}$terdiri dari 23 siswa,kelas $\mathrm{II}^{-2}$ terdiri dari 32 siswa, dan kelas $\mathrm{II}^{3}{ }^{3}$ terdiri dari 20 siswa. Total populasi penelitian ini adalah 74 siswa. Sampel Penelitian ini, peneliti mengambil satu kelas sebagi sample yaitu kelas II- $^{1}$ terdiri dari 23 siswa. Teknik pengambilan sampel penelitian menggunakan kelas cluster random sampling. Instrumen Penelitian yang digunakan dalam pengumpulan data penelitian yaitu tes pilihan pilihan ganda untuk mengukur hasil belajar kosakata siswa terdiri atas 25 butir dengan berbagai varian soal dan kuesioner dengan skala alternatif pilihan jawaban untuk mengukur minat belajar kosakata siswa. Hasil yang ditemuka bahwa jawaban: sangat setuju diberikan skor 5, setuju diberikan skor 4, skor diberikan ragu 3, tidak setuju skor diberikan 2, dan sangat tidak setuju diberikan skor dalam hal ini penelitian kuesioner sebagai data utama dengan menggunakan metode deskripsi yang melibatkan deskripsi dan interpretasi data. Peneliti menggunakan kuesioner untuk mengetahui motivasi siswa dalam membaca. Hail analisisa data deskripsi skor niali rata-rata deviasi pre-tes dan Post-tes kusioner siswa diperoleh dengan membagi jumlah skor deviasi dengan jumlah siswa dapat dilihat $194 / 23=8.435$. Dalam penelitian ini, sampel data adalah 23 siswa, sehingga tingkat kebebasan (df) yang digunakan 23-1 $=22$. Setelah menghitung interpetasi data ditemukan bahwa t-tes $=9.467 \geq \mathrm{t}$-tabel $=1.717$. Dari hasil di atas, peneliti menyimpulkan bahwa teknik word category memiliki pengaruh yang signifikan terhadap pemahaman membaca siswa. Oleh karena itu, Hipotesis Alternatif diterima dan Hipotesis Null ditolak
\end{abstract}

Kata Kunci: Word Category, Kosakata, Minat siswa.

\section{PENDAHULUAN}

Berdasarkan hasil pengamatan yang dilakukan di salah satu sekolah negeri, tepatnya di SMPN 1 Praya Barat. Peneliti menemukan beberapa siswa mengalami kesulitan dalam pembelajaran bahasa Inggris 
yang terefleksikan pada masih sulitnya siswa memahami dan menggunakan kosakata bahasa Inggris dengan baik. Kesulitan-kesulitan tersebut diantaranya yang pertama siswa sulit untuk memahami arti kata-kata misalnya yang terdapat pada frasa"Hi guys" ("Hai temanteman). Would you like to drop in?" (Apakah Anda ingin mampir?"), karena beberapa siswa memiliki definisi yang keliru tentang makna kalimat, yang kedua siswa masih belum bisa menggunakan kata-kata dengan baik misalnya ketika guru meminta siswa untuk membuat kalimat pendek tentang meminta izin (asking for permission). Beberapa siswa bingung karena mereka tidak mengerti bagaimana membahasakan ungkapan tersebut dengan penggunaan kata yang tepat dan sesuai, dan yang ketiga adalah siswa juga masih kekurangan dalam hal ejaan kata. Misalnya ketika peneliti meminta siswa mengeja kata "Hi guys". Would you like to drop in?" beberapa siswa mengatakan tidak bisa mengejanya karena mereka jarang mengeja kata tersebut. Hal ini berakibat pada kurangnya minat siswa dalam mempelajari bahasa Inggris di sekolah. Dilihat dari urgensi masalah di atas dimana beberapa kata mungkin memiliki lebih dari dua makna, dan mungkin memiliki lebih dari tiga makna dan pembelajaran kosakata yang digunakan para guru sejauh ini belum mampu untuk menarik minat siswa dalam belajar bahasa Inggris secara maksimal. Selain itu, ada beberapa faktor yang mempengaruhi minat siswa dalam proses belajar bahasa Inggris seperti jadwal untuk mata pelajaran bahasa Inggris yang sering dijadwalkan pada akhir-akhir jam pelajaran. Kondisi demikian seringkali membuat siswa merasa kurang antusias dalam belajar dan bahkan tidak fokus dalam belajar di kelas. Dalam proses belajar mengajar, guru bahasa Inggris kadang-kadang hanya memberikan materi kepada siswa tanpa penjelasan lebih lanjut, kadang-kadang hanya memberi mereka tugas, dan mereka kurang berlatih di kelas. Ketika guru mengajar di kelas, guru menggunakan metode tradisional dan tidak menggunakan wadah lain seperti media permainan dalam mendukung proses pembelajaran yang membuat siswa lebih mudah memahami materi. Berdasarkan hal tersebut maka diperlukan pendekatan lain dalam pembelajaran bahasa Inggris agar mampu meningkatkan minat dan prestasi belajar kosakata siswa sehingga berdampak pula pada hasil belajar bahasa Inggris siswa di sekolah salah satunya adalah media (M. Syaeful, M. et.al (2013). Senada dengan apa yang disampaikan oleh Biyansahna, E. dan Riyan, M. (2020) mengatakan bahwa media samgat membantu terutama untuk menghidari kesalapahaman dari pertanyaan kearena siswa dapat berhubungan dengan gambar yang diberikan. Pada penelitian ini word category dapat dikatakan gambar atau media yang berbentuk kata-kata acak. Word category adalah model pembelajaran kosa kata bermain sambil belajar, Permainannya simple dengan dengan yang dikenal sebagai 'Identifikasi' dapat diadaptasi untuk memasukkan kosa kata dengan cukup mudah. (Marsland, 1998: 16). Sebuah kemungkinan tindak lanjutnya, dengan menggunakan kosakata yang telah diidentifikasi, kata menjadi sebuah aktivitas. Menggunakan berbagai permainan dapat membantu siswa menghafal kosakata atau tata bahasa. Mereka sering menjadi begitu terlibat dalam permainan sehingga mereka berhenti merasa cemas tentang kesalahan mereka. Kosakata adalah elemen terpenting dalam suatu bahasa. Siswa tidak dapat berbicara bahasa dengan baik jika siswa tidak menguasainya tidak peduli seberapa baik siswa belajar tata bahasa, seberapa sukses suara asing dikuasai, tanpa kata-kata untuk mengekspresikan jangkauan makna yang lebih luas. Ada beberapa definisi kosakata yang dikemukakan oleh beberapa pakar, yaitu: Caroline (2005: 121) mengatakan bahwa kosakata adalah kolokasi kata-kata yang diketahui seseorang. Jadi, bahasa diatur oleh begitu banyak kata dan frasa. Secara umum, kosakata adalah pengetahuan tentang makna kata, menurut Thornburry (2002: 25) kosakata adalah komponen bahasa yang memberikan informasi atau penjelasan dalam suatu istilah bahasa. Selain itu, ada definisi kosakata lain, yaitu: menurut: Hiebert (2005: 3) bahwa kosakata adalah pengetahuan tentang makna kata-kata. Ini berarti bahwa kosakata adalah salah satu yang harus dipertimbangkan dalam pengembangan bahasa. Berdasarkan 
pernyataan-pernyataan di atas peneliti menyimpulkan bahwa kosakata adalah daftar kata dalam bahasa dengan makna dan definisi dan sangat penting untuk mengembangkan kemampuan siswa dalam belajar berbicara, mendengarkan, membaca, dan menulis sebagai dasar dalam belajar bahasa dan untuk terapkan dalam hidup mereka dengan bermakna. Selain itu, kosakata juga merupakan kata atau suara yang mewakili makna tertentu sebagai kesatuan ucapan. Ini adalah bagian terpenting dalam pembelajaran bahasa untuk mencapai empat keterampilan, seorang siswa harus memperoleh kosakata, dan seorang siswa perlu meningkatkan penguasaan kosakata mereka juga. Jelas bahwa kosakata adalah dasar dari bahasa. Jadi, tidak ada bahasa tanpa kosakata. Minat dapat dikembangkan melalui motivasi. Seorang guru yang bijaksana akan memotivasi muridnya sebelum pelajaran di kelas. Nasution (1977:87) mengatakan bahwa motivasi adalah semua sumber daya untuk mendorong seseorang melakukan sesuatu. Saya percaya bahwa untuk membuat siswa tertarik membaca, motivasi diperlukan. Membaca dalam arti terbatas atau dalam arti luas itu menarik. minat memotivasi seseorang untuk membaca dan berusaha karena pemilihan bacaan menarik biasanya seseorang lebih tahu tentang topik di mana dia tertarik yang membuat pemahaman bacaan lebih mudah. Oleh karena itu perlu untuk menyajikan beberapa definisi atau teori yang menarik seperti yang diusulkan oleh psikolog untuk memiliki deskripsi yang jelas tentang apa itu minat. Bloom (1971: 16-17) mendefinisikan minat sebagai perilaku dalam hal apakah individu akan secara sukarela terlibat dalam tugas-tugas pembelajaran tambahan dan mereka bebas untuk membuat pilihan seperti itu. Lebih lanjut ia menjelaskan bahwa minat dapat didefinisikan secara lebih subyektif dalam hal kesukaan, antusiasme, preferensi, dan keinginan individu. Prestasi belajar merupakan capaian atau hasil yang diperoleh sesesorang setelah melalui ujian dalam proses pembelajaran. Hal ini sebagaimana yang dikemukakan oleh Winkel (1996:96) dalam bahwa prestasi belajar merupakan suatu bukti yang menunjukkan kemampuan dan keberhasilan seseorang yang melakukan proses belajar sesuai dengan bobot atau nilai yang dihasilkannya. Sejalan dengan Winkel, Nasution (1996:96) memberikan penjelasan terkait pengertian prestasi belajar secara lebih rinci yaitu kesempurnaan seorang peserta didik dalam berpikir, berbuat dan merasa dalam proses pendidikan yang ditandai pada 3 aspek yaitu (1) aspek kognitif dimana seorang peserta didik dapat menujukkan kemampuan berpikir cemerlang atau dengan kata lain menonjol pada segi intelejensia, (2) psikomotorik yaitu keterampilan baik scara fisik dan mental yang ditunjukkan oleh peserta didik setelah memperoleh pengetahuan dalam proses pembelajaran, dan (3) aspek afektif yaitu seorang peserta didik tidak hanya mampu dalam mengembangkan kemampuan berpikir, tetapi juga mampu untuk menjaga kecerdasan emosional melalui sikap disiplin dan kepatuhan. Dalam pengajaran bahasa Inggris terdapat bermacam teknik yang dapat digunakan dianataranya seperti word map atau word mapping, yaitu organisator visual yang mempromosikan pengembangan kosakata, word associated or semantics meaning, yaitu membangun hubungan antara kata-kata yang berdampingan dan memperjelas arti kalimat. Selain itu, Word category atau kategori kata yaitu permainan kosakata yang dikenal juga sebagai 'identifikasi kata' untuk memasukkan kosakata berdasarkan kategori dengan cukup mudah. Penggunaan media game word category dapat membuat siswa akan banyak terlibat lebih aktif dalam sebuah permainan sehingga mereka tidak merasa takut apabila melakukan kesalahan (Marsland,1998:16). Word category merupakan salah satu media yang dapat membantu guru dalam pelaksanaan proses pembelajaran. Media mengajar kosakata yang menarik mempengaruhi minat siswa dalam belajar sehingga membuat siswa akan lebih mudah memahami materi pembelajaran yang disampaikan. Karena kosakata adalah satu komponen bahasa yang harus dikuasi karena akan mendukung keterampilan bahasa lainnya seperti, mendengarkan, berbicara, membaca dan menulis (C.P. Proctor et.al 2011:517-544). Sedangkan menurut Thornburry (2020:20) in Sripuddin, M. and Tearasne, T., mengatakan bahawa penguasaan kosakata dianggap penting 
sebagai dasar pembelajaran keterampilan bahasa Inggris. Karena tanpa penguasaan kosakata yang baik tentu dapat berdampak negatif terhadap upaya penguasaan keterampilan bahasa Inggris lainnya. Untuk mengatasi masalah ini peneliti akan mengadakan penelitian dengan judul "Efektivitas Penggunaan Word Category terhadap Peningkatan Minat dan Prestasi Belajar Kosakata pada Pembelajaran Bahasa Inggris Siswa SMPN 1 Praya Barat". Penggunaan Word Category atau Kategori kata sebagai strategi jitu yang dapat membantu guru untuk mengajar bahasa Inggris dengan lebih menyenangkan dan lebih aktif pada saat dilakukannya proses pembelajaran di dalam kelas. Diharapkan hasil penelitian ini dapat dijadikan media alternatif bagi guru khususnya guru bahasa Inggris dalam upaya mengenal dan menguasai kosakata dengan berbagai varian kategori dan jenis kata serta minat belajar bahasa Inggris siswa. Tujuan penelitian ini adalah untuk mengetahui efektivitas penggunaan Word Category terhadap peningkatan minat dan prestasi belajar kosakata pada mata pelajaran bahasa Inggris siswa SMPN 1 Praya Barat. Hasil penelitian ini secara teoritis diharapkan dapat menjadi pengayaan wawasan dalam pembelajaran bahasa Inggris, khususnya dalam hal penggunaan media belajar word category dan manfaat Praktis penelitian ini dapat dijadikan media alternatif bagi guru dalam upaya mendorong minat dan prestasi belajar kosakata siswa dalam pembelajaran bahasa Inggris di kelas, untuk siswa dapat menjadi gambaran bagi siswa tentang media yang efektif untuk menambah penguasaan perbendaharaan kosakata siswa secara menarik melalui permainan kosakata berbasis media dan untuk peneliti dapat menjadi rujukan bagi para peneliti lain untuk memperkuat hasil penelitian terkait atau dapat dijadikan sebagai rujukan awal untuk melakukan penelitian lanjutan terkait penggunaan media word category dalam pembelajaran bahasa Inggris, khususnya dalam upaya peningkatan perbendaharaan kosakata bahasa Inggris siswa.

\section{KAJIAN LITERATURE DAN PENGEBANGAN HIPOTHESIS Word Category}

Word category adalah model pembelajaran kosa kata bermain sambil belajar, Permainannya simple dengan dengan yang dikenal sebagai 'Identifikasi' dapat diadaptasi untuk memasukkan kosa kata dengan cukup mudah. (Marsland, 1998: 16).

\section{Kosakata}

Kosakata adalah elemen terpenting dalam suatu bahasa. Siswa tidak dapat berbicara bahasa dengan baik jika siswa tidak menguasainya tidak peduli seberapa baik siswa belajar tata bahasa, seberapa sukses suara asing dikuasai, tanpa kata-kata untuk mengekspresikan jangkauan makna yang lebih luas. Ada beberapa definisi kosakata yang dikemukakan oleh beberapa pakar, yaitu: Caroline (2005: 121) mengatakan bahwa kosakata adalah kolokasi kata-kata yang diketahui seseorang. Jadi, bahasa diatur oleh begitu banyak kata dan frasa. Secara umum, kosakata adalah pengetahuan tentang makna kata, menurut Thornburry (2002: 25) kosakata adalah komponen bahasa yang memberikan informasi atau penjelasan dalam suatu istilah bahasa. Selain itu, ada definisi kosakata lain, yaitu: menurut: Hiebert (2005: 3) bahwa kosakata adalah pengetahuan tentang makna kata-kata. Ini berarti bahwa kosakata adalah salah satu yang harus dipertimbangkan dalam pengembangan bahasa. Berdasarkan pernyataan-pernyataan di atas peneliti menyimpulkan bahwa kosakata adalah daftar kata dalam bahasa dengan makna dan definisi dan sangat penting untuk mengembangkan kemampuan siswa dalam belajar berbicara, mendengarkan, membaca, dan menulis sebagai dasar dalam belajar bahasa dan untuk terapkan dalam hidup mereka dengan bermakna. Selain itu, kosakata juga merupakan kata atau suara yang mewakili makna tertentu sebagai kesatuan ucapan. Ini adalah bagian terpenting dalam pembelajaran bahasa untuk mencapai empat keterampilan, seorang siswa harus memperoleh kosakata, dan seorang siswa perlu meningkatkan penguasaan kosakata mereka juga. Jelas bahwa kosakata adalah dasar dari bahasa. Jadi, tidak ada bahasa tanpa kosakata.

\section{Minat Belajar}

Minat dapat dikembangkan melalui motivasi. Seorang guru yang bijaksana akan memotivasi muridnya sebelum pelajaran di 
kelas. Nasution (1977:87) mengatakan bahwa motivasi adalah semua sumber daya untuk mendorong seseorang melakukan sesuatu. Saya percaya bahwa untuk membuat siswa tertarik membaca, motivasi diperlukan. Membaca dalam arti terbatas atau dalam arti luas itu menarik. minat memotivasi seseorang untuk membaca dan berusaha karena pemilihan bacaan menarik biasanya seseorang lebih tahu tentang topik di mana dia tertarik yang membuat pemahaman bacaan lebih mudah. Oleh karena itu perlu untuk menyajikan beberapa definisi atau teori yang menarik seperti yang diusulkan oleh psikolog untuk memiliki deskripsi yang jelas tentang apa itu minat. Bloom (1971: 16-17) mendefinisikan minat sebagai perilaku dalam hal apakah individu akan secara sukarela terlibat dalam tugas-tugas pembelajaran tambahan dan mereka bebas untuk membuat pilihan seperti itu. Lebih lanjut ia menjelaskan bahwa minat dapat didefinisikan secara lebih subyektif dalam hal kesukaan, antusiasme, preferensi, dan keinginan individu.

\section{Penelitian Relevan}

Penelitian yang melibatkan penggunaan media word category dalam pembelajaran bahasa Inggris bukanlah untuk yang pertama kali. Diantara peneltian terdahulu yang pernah diteliti sebelumnya dan relevan dengan penelitian ini yaitu sebagaimana yang telah diteliti oleh Almagarbeh dengan judul The Influence of Words Categories on Translating Postgraduate Abstracts in the Field of Evaluation and Measurement at Mu'tah University (2015). Adapun rumusan permasalahan yang diajukan dalam penelitiannya adalah (1) Sejauh mana pengaruh kategori kata dalam menerjemahkan abstrak pascasarjana di bidang Evaluasi dan Pengukuran?; dan (2) bagaimana cara penerjemah translatabilitas kategori kata? Berdasarkan hasil penelitiannya, diperoleh hasil yang menunjukkan bahwa ada hubungan yang signifikan antara kategori kata dan kemampuan terjemahan. Penerjemah setuju bahwa penggunaan kategori termasuk kata benda, kata ganti, kata kerja, kata kerja phrasal, modals dan preposisi. Terasne (2015) yang berjudul " Improving Students' Vocabulary Mastery trough Word Map
Technique at the First Students Semster of IKIP Mataram". Tujuan Penelitian ini adalah untuk mengetahui, apakah dengan menggunakan Peta Kata dapat meningkat penguasaan Kosakata siswa pada mahasiswa IKIP Mataram in academic year 2014/2015. Untuk mengetahui Bagaimanakah pelaksanaan pengajaran kosakata bahasa Inggris melalui teknik Peta Kosakata. Sample terdiri dari 1 kelas yang diambil dengan cluster random sampling. Kerangka penelitian menggunkan penerapan berdasarakan keempat tahap pretest kegitan awa, kegitan inti dan post-test. Teknik pengumpulan data adalah data kualitatif yang berupa deskripsi dari angket tanggapan siswa. Hasil dari pre-test adalah 69.39. Hal ini tersirat bahwa yang pertama tidak memenuhi, tetapi kita bisa melihat peningkatan setelah siswa diajarkan dengan menggunaan Pemetaan Kata dengan nilai rata-rata pada post-test adalah 79.39 dan presentase nilai resepon siswa dari setip items. Peresentasi items pertama adalah (77.43\%) presentase Itms kedua adalah (62.07\%) presentase Itms ketiga adalah $(63.70 \%)$ presentase Itms keempat adalah $(66.10 \%)$. Terasne, T. (2016) yang berjudul" The Effectiveness of Using Word Map Techinque in teaching vocabulray at third Grade Students of IKIP Mataram" Tujuan penelitian ini untuk mengetahui efektivitas penggunaan Teknik "Word Map" dalam pengajaran kosakata siswa pada mahasiswa semester tiga IKIP Mataram pada tahun akademik 2015/2016. Penelitian ini adalah penelitian eksperimental semu. Sampel penelitian ini adalah dua kelas, yaitu kelas A dan kelas B yang terdiri dari 39 siswa yamg diambil dengan menggunakan cluster random sampling. Sampel penelitian dibagi menjadi dua kelompok yaitu kelompok eksperimen dan kelompok kontrol. Kelompok eksperimen diajarkan menggunkan Teknik Pemetaa kosakata dan kelompok kontrol diajarkan dengan menggunkan Teknik Tiga Fase. Kerangka penelitian menggunkan penerapan berdasarakan keempat tahap pre-test kegitan awa, kegitan inti dan post-test. Instrumen test adalah test pilihan ganda terdiri dari 25 setiap jawaban yang benar mendapatkan skor 4 dan jawaban yang salah mendatakan skor 0 . Berdasarkan analisis data ditemukan bahwa 
skor t-test adalah 7.743 dan t-tabel 1.668. Hasil penelitian menunjukkan bahwa nilai ttest tertinggi maka nilai t-tabel. Dapat disimpulkan bahwa ada pengaruh yang signifikan dari Teknik Peta Kata dalam pengajaran kosakata pada siswa kelas tiga IKIP Mataram pada tahun akademik 2015/2016. Dari hasil penelitian dapat ditarik kesimpulan tentang perlunya penggunaan word categori sebagai media alternatif dalam upaya peningkatan minat dan prestasi belajar kosakata siswa.

\section{Hipotesis Penelitian}

a) Hipotesis penelitian ini sebagai berikut:

Ha: Penggunaan Word Category efektif terhadap peningkatan minat dan prestasi belajar kosakata pada mata pelajaran bahasa Inggris siswa SMPN 1 Praya Barat.

b) Ho: Penggunaan Word Category tidak efektif terhadap peningkatan minat dan prestasi belajar kosakata pada mata pelajaran bahasa Inggris siswa SMPN 1 Praya Barat.

\section{METODE PENELITIAN}

\section{Desain Penelitian}

Desain penelitian ini adalah desain onegroup pre test-pos-test, dimana dalam model ini terdapat satu kelompok eksperimen kemudian diberi pre-tes untuk mengetahui keadaan awal kelompok eksperimen, selanjutnya diberikan perlakuan dan diberikan post-tes untuk mengetahui hasil selama diberikan perlakuan. Desain penelitian preeksperimental ini dapat digambarkan sebagai berikut.

Tabel 3.1.

Gambar Desain One Group Pre-Tes Pos-tes

\begin{tabular}{|c|c|c|}
\hline Pre-test & Perlakuan & Post-test \\
\hline $\mathrm{O}_{1}$ & $\mathrm{X}$ & $\mathrm{O}_{2}$ \\
\hline
\end{tabular}

\section{Keterangan:}

$\mathrm{O}_{1}=$ Nilai Pre-test (sebelum diberi perlakuan penggunaan word category)

$\mathrm{X}=$ Perlakuan

$\mathrm{O}_{2}=$ Nilai Post-test (sesudah diberi perlakuan penggunaan word category)

Berdasarkan rancangan penelitian tersebut, ditetapkan satu kelompok experiment yakni kelas 2 untuk mengetahui ada tidaknya minat. Hal tersebut bisa dilihat dari pre-tes dan pos-tes tersebut.

\section{Populasi}

Menurut Miller (1984: 45) istilah populasi Populasi penelitian ini adalah siswa kelas II SMPN 1 Praya Barat yang terdiri dari 3 kelas. Siswa kelas IIdi Sekolah ini dibagi menjadi tiga kelas; mereka adalah kelas II- $^{1}$ yang terdiri dari 23 siswa, dan $\mathrm{II}^{-}{ }^{2}$ yang terdiri dari 32 siswa, dan kelas II- $^{3}$ terdiri dari 20 siswa. Total populasi penelitian ini adalah 74 siswa.

\section{Sampel}

Kothari (2004: 158) sampel mengacu pada bagian alam semesta yang dipilih untuk tujuan penyelidikan Dalam menemukan sampel. Penelitian ini, peneliti mengambil satu kelas sebagi sample yaitu kelas II- ${ }^{1}$

\section{Teknik Sampling}

Teknik pengambilan sampel penelitian menggunakan kelas cluster random sampling. Kothari (2004: 16) mengemukakan bahwa Cluster random sampling melibatkan pengelompokan populasi dan kemudian memilih kelompok atau kelompok daripada elemen individu untuk dimasukkan dalam sampel.

\section{Teknik Pengumpulan Data Pre-test}

Sebelum siswa diberikan perlakuan selama beberapa pertemuan siswa diberikan tes yang terdiri atas tes minat belajar menggunakan kuesioner dan tes hasil belajar menggunakan pilihan ganda. Pre-tes ini dimaksudkan untuk mengetahui kemampuan awal siswa sebelum penggunaan media word category dalam proses pembelajaran bahasa Inggris di kelas

\section{Perlakuan}

Pada sesi perlakuan ini siswa akan diajarkan belajar mengenal dan mengidentifikasi berbagai jenis kosakata bahasa Inggris menggunakan media Word Category.

\section{Post-tes}

Setelah siswa diberikan perlakuan selama beberapa pertemuan selanjutnya siswa akan diberikan tes yang terdiri atas tes minat belajar menggunakan kuesioner dan tes hasil belajar menggunakan pilihan ganda. Tes lanjutan ini dimaksudkan untuk mengetahui seberapa besar pengaruh penggunaan word 
category selama dilaksanakannya proses pembelajaran bahasa Inggris di kelas

\section{Instrumen Penelitian}

Ada dua jenis instrumen yang digunakan dalam pengumpulan data penelitian yaitu tes pilihan ganda dan kuesioner. Tes pilihan ganda digunakan untuk mengukur hasil belajar kosakata siswa. Soal pilihan ganda terdiri atas 25 butir dengan berbagai varian soal. Kemudian kuesioner digunakan untuk mengukur minat belajar kosakata siswa. Kuesioner minat menggunakan skala likert dengan beberapa alternatif pilihan jawaban. Sebelum instrumen penelitian digunakan terlebih dahulu akan dilakukan uji validitas dan reliabilitas.

\section{Validitas Instrumen}

Menurut Kothari (2004:73) Validitas adalah kriteria paling kritis dan menunjukkan sejauh mana instrumen mengukur apa yang seharusnya diukur. Dengan kata lain, Validitas adalah sejauh mana perbedaan yang ditemukan dengan alat ukur mencerminkan perbedaan yang sebenarnya di antara mereka yang diuji. Di. penelitian ini validitas item yang diperoleh dengan menggunakan SPSS 23.0 for window dengan Pearson Product Moment. Nilai $r$ product moment dalam tes ini adalah $0,413 \mathrm{di}$ mana korelasi signifikansi 5\%. Jika r diperoleh $\geq \mathrm{r}$ tabel berarti item itu valid. Ada 25 item tes membaca dan 25 kuesioner sebelum menguji validitas dan reliabilitas. Setelah menganalisis validitas instrumen, peneliti menemukan 25 item tes membaca valid dan 20 item kuesioner valid.

\section{Reliabilitas Instrumen}

Menurut Kothari (2004: 74), uji reliabilitas merupakan tes penting lainnya untuk pengukuran suara. Alat ukur dapat diandalkan jika memberikan hasil yang konsisten. Instrumen yang andal akan dapat memberikan data berdasarkan kondisi nyata sampel.

Tes yang andal konsisten dan dapat diandalkan (Brown, 2004: 20). Instrumen yang andal memberikan hasil yang sama walaupun telah diuji beberapa kali. Untuk mengetahui keandalan suatu instrumen, peneliti menggunakan SPSS 23.0 untuk Windows dengan metode Cronbach. Jika $r$ diperoleh $\geq r$ tabel berarti item tersebut dapat diandalkan.
Setelah menganalisis reliabilitas instrumen, peneliti menemukan reliabilitas instrumen membaca $r$ diperoleh $0,717 \geq 0413 \mathrm{r}$ tabel, dan reliabilitas angket $r$ diperoleh $0,638 \geq 0,374 \mathrm{r}$ tabel, sehingga instrumen bacaan dan angket reliabel.

\section{Teknik Pengumpulan Data}

Untuk mengetahui motivasi siswa, peneliti memberikan tes kuesioner yang terdiri dari 20 item yang valid dalam bentuk skala likert atau dengan lima alternatif jawaban: sangat setuju diberikan skor 5, setuju diberikan skor 4, skor diberikan ragu-ragu 3, skor diberikan tidak setuju 3, tidak setuju diberikan skor 2 , dan sangat tidak setuju diberi skor 1 .

Uji Dalam penelitian ini peneliti menggunakan pre-test dan post-test. Langkah pertama untuk mengumpulkan data, peneliti memberi siswa tes awal, karena peneliti ingin mengetahui motivasi siswa tentang

pemahaman membaca. Prosedur selanjutnya adalah post-test, tes diberikan setelah peneliti memperlakukan siswa dengan teknik word category. Tes ini digunakan beberapa pilihan. Ini bertujuan untuk mengetahui hasil yang signifikan setelah siswa diperlakukan pemahaman mereka dengan menggunakan strategi word category. Tes memiliki tingkat kesulitan yang sama dengan yang diberikan pada pra-tes. Penulis memberikan tes kepada semua siswa sampel dan meminta mereka untuk melakukan tes secara individual dan hati-hati. Setelah itu, lembar kertas siswa diserahkan dan peneliti memisahkan lembar jawaban siswa yang dipilih sebagai sampel dengan siswa yang tidak. Akhirnya hasil siswa diperlakukan sebagai data. Setelah mendapatkan hasil tes, maka akan dinilai.

\section{Teknik Data Analalis Metode Menganalisis Kuisioner}

Kuisioner adalah teknik pengumpulan data dengan memberikan beberapa pertanyaan atau pernyataan untuk responden. Peneliti memberikan tes kuesioner yang terdiri dari 20 item dalam bentuk skala likert atau dengan lima alternatif jawaban: sangat setuju diberikan skor 5, setuju diberikan skor 4, skor diberikan ragu 3, tidak setuju skor diberikan 2, dan sangat tidak setuju diberikan skor dalam 
hal ini penelitian kuesioner sebagai data utama dengan menggunakan metode deskripsi yang melibatkan deskripsi dan interpretasi data. Peneliti menggunakan kuesioner untuk mengetahui motivasi siswa dalam membaca. Dalam menganalisis motivasi siswa dalam membaca, peneliti menggunakan rumus:

$$
\mathrm{fs}=\frac{\text { amount of obtained score }}{\text { amount of ideal score far all items }} \times 100 \%
$$

Sugiyono, 2014: 94

\section{Inferential Analysis}

Analisis inferensial membuat kesimpulan secara umum tentang data yang telah disusun atau diproses. Tujuan analisis inferensial untuk menjawab atau menguji hipotesis, apakah cuaca itu diterima atau ditolak

\section{HASIL DAN PEMBAHASAN \\ Deskripsi Data Tes Kosakata}

Deskripsi data di bawah ini menunjukkan bahwa skor pre-test tertinggi adalah 64, skor terendah adalah 8 dan skor rentang skor pre-test adalah 56. Sementara itu, skor tertinggi dari post-test adalah 92, skor terendah adalah 52 dan skor skor rentang posttest adalah 40. Tabel berikut menunjukkan hasil skor pre-test dan post-test siswa secara rinci.

Tabel 4.1

Skor Pra-Tes dan Pasca Tes Siswa dalam Tes kosakata

\begin{tabular}{|c|l|c|c|c|}
\hline No. & $\begin{array}{c}\text { Kode } \\
\text { siswa }\end{array}$ & $\begin{array}{c}\text { Pre- } \\
\text { Tes }\end{array}$ & $\begin{array}{c}\text { Post- } \\
\text { Tes }\end{array}$ & $\begin{array}{c}\text { Deviasi } \\
\text { (D) }\end{array}$ \\
\hline 1. & $\mathrm{~V}-1$ & 44 & 84 & 40 \\
\hline 2. & $\mathrm{~V}-2$ & 40 & 80 & 40 \\
\hline 3. & $\mathrm{~V}-3$ & 32 & 80 & 48 \\
\hline 4. & $\mathrm{~V}-4$ & 64 & 88 & 24 \\
\hline 5. & $\mathrm{~V}-5$ & 36 & 80 & 44 \\
\hline 6. & $\mathrm{~V}-6$ & 60 & 92 & 32 \\
\hline 7. & $\mathrm{~V}-7$ & 60 & 92 & 32 \\
\hline 8. & $\mathrm{~V}-8$ & 64 & 84 & 20 \\
\hline 9. & $\mathrm{~V}-9$ & 60 & 92 & 32 \\
\hline 10. & $\mathrm{~V}-10$ & 40 & 80 & 40 \\
\hline 11. & $\mathrm{~V}-11$ & 40 & 84 & 44 \\
\hline 12. & $\mathrm{~V}-12$ & 44 & 76 & 32 \\
\hline 13. & $\mathrm{~V}-13$ & 32 & 72 & 40 \\
\hline 14. & $\mathrm{~V}-14$ & 56 & 84 & 28 \\
\hline 15. & $\mathrm{~V}-15$ & 56 & 92 & 36 \\
\hline 16. & $\mathrm{~V}-16$ & 28 & 80 & 52 \\
\hline 17. & $\mathrm{~V}-17$ & 36 & 88 & 52 \\
\hline
\end{tabular}

\begin{tabular}{|c|c|c|c|c|}
\hline 18. & V-18 & 48 & 76 & 28 \\
\hline 19. & V-19 & 52 & 76 & 24 \\
\hline 20. & V-20 & 32 & 72 & 40 \\
\hline 21. & $V-21$ & 44 & 80 & 44 \\
\hline 22. & $V-22$ & 44 & 88 & 44 \\
\hline 23 & $V-23$ & 8 & 52 & 44 \\
\hline \multicolumn{2}{|r|}{$\Sigma$} & 1020 & 1872 & 860 \\
\hline
\end{tabular}

a) Deskripsi Data Kuisioner pada Pre-tes siswa

Deskripsi data kuisioner pre-tes menunjukkan bahwa skor tertinggi adalah 83, skor terendah adalah 66 dan skor rentang skor pre-tes adalah 17. Tabel berikut menunjukkan hasil skor pre-test siswa.

Tabel.4.2 skor Pre-tes siswa

\begin{tabular}{|c|c|c|c|c|c|c|c|}
\hline \multirow[t]{2}{*}{ No. } & \multirow[t]{2}{*}{ Kode } & \multicolumn{5}{|c|}{ Jawaban responden } & \multirow{2}{*}{$\begin{array}{l}\text { Skor } \\
\text { tota }\end{array}$} \\
\hline & & $\begin{array}{l}\text { SS } \\
\text { (5) }\end{array}$ & $\begin{array}{c}S \\
(4)\end{array}$ & $\begin{array}{c}R \\
\text { (3) }\end{array}$ & $\begin{array}{l}\text { TS } \\
\text { (2) }\end{array}$ & $\begin{array}{l}\text { STS } \\
\text { (1) }\end{array}$ & \\
\hline 1. & V-1 & 1 & 11 & 8 & - & - & 73 \\
\hline 2. & $V-2$ & 2 & 9 & 5 & 4 & - & 67 \\
\hline 3. & V-3 & 3 & 8 & 9 & - & - & 74 \\
\hline 4. & $\mathrm{~V}-4$ & 5 & 5 & 10 & - & - & 75 \\
\hline 5. & V-5 & 3 & 9 & 7 & 1 & - & 74 \\
\hline 6. & V-6 & 2 & 8 & 10 & - & - & 72 \\
\hline 7. & $V-7$ & 3 & 9 & 8 & - & - & 75 \\
\hline 8. & V-8 & 4 & 6 & 10 & - & - & 74 \\
\hline 9. & V-9 & 6 & 9 & 5 & - & - & 81 \\
\hline 10. & V-10 & 4 & 9 & 7 & - & - & 77 \\
\hline 11. & V-11 & 3 & 6 & 9 & 2 & - & 70 \\
\hline 12. & $\mathrm{~V}-12$ & 3 & 10 & 7 & - & - & 76 \\
\hline 13. & V-13 & 3 & 6 & 11 & - & - & 72 \\
\hline 14. & V-14 & 3 & 5 & 12 & - & - & 71 \\
\hline 15. & V-15 & 7 & 9 & 4 & - & - & 83 \\
\hline 16. & V-16 & 2 & 7 & 8 & 3 & - & 66 \\
\hline 17. & V-17 & 3 & 7 & 10 & - & - & 69 \\
\hline 18. & V-18 & 3 & 6 & 8 & 3 & - & 69 \\
\hline 19. & V-19 & 2 & 9 & 9 & - & - & 73 \\
\hline 20 & $V-20$ & 2 & 11 & 7 & - & - & 73 \\
\hline 21. & $V-21$ & 1 & 10 & 8 & 1 & - & 71 \\
\hline 22. & $V-22$ & 2 & 6 & 12 & - & - & 70 \\
\hline 23. & V-23 & 3 & 9 & 6 & 2 & - & 73 \\
\hline & $\Sigma$ & 70 & 184 & 190 & 16 & - & 1680 \\
\hline
\end{tabular}

\section{b) Deskripsi Data Kuisioner Post-tes siswa}

Deskripsi Data Kuisioner Post-tes menunjukkan bahwa skor tertinggi adalah 88 , skor terendah adalah 75 dan skor rentang skor post-test adalah 13. Tabel berikut menunjukkan hasil skor siswa dari pos-tes .

\section{Tabel 4.3 Skor post tes siswa}




\begin{tabular}{|c|c|c|c|c|c|c|c|}
\hline \multirow[t]{2}{*}{ No. } & \multirow[t]{2}{*}{ Kode } & \multicolumn{5}{|c|}{ Jawaban siswa } & \multirow{2}{*}{$\begin{array}{l}\text { Skor } \\
\text { total }\end{array}$} \\
\hline & & $\begin{array}{l}\text { SS } \\
\text { (5) }\end{array}$ & $\begin{array}{c}S \\
\text { (4) }\end{array}$ & $\begin{array}{c}R \\
\text { (3) }\end{array}$ & $\begin{array}{l}\text { TS } \\
\text { (2) }\end{array}$ & $\begin{array}{l}\text { STS } \\
\text { (1) }\end{array}$ & \\
\hline 1. & V-1 & 3 & 9 & 8 & - & - & 75 \\
\hline 2. & V-2 & 4 & 10 & 4 & 2 & - & 76 \\
\hline 3. & V-3 & 5 & 11 & 4 & - & - & 81 \\
\hline 4. & $V-4$ & 5 & 12 & 3 & - & - & 82 \\
\hline 5. & $V-5$ & 7 & 7 & 6 & - & - & 81 \\
\hline 6. & V-6 & 3 & 15 & 2 & - & - & 81 \\
\hline 7. & V-7 & 4 & 10 & 5 & 1 & - & 77 \\
\hline 8. & $V-8$ & 6 & 11 & 3 & - & - & 83 \\
\hline 9 & V-9 & 10 & 8 & 2 & - & - & 88 \\
\hline 10. & V-10 & 5 & 13 & 2 & - & - & 83 \\
\hline 11. & V-11 & 5 & 10 & 3 & 2 & - & 78 \\
\hline 12. & V-12 & 6 & 9 & 5 & - & - & 81 \\
\hline 13. & V-13 & 4 & 12 & 4 & - & - & 80 \\
\hline 14. & V-14 & 6 & 10 & 4 & - & - & 82 \\
\hline 15. & V-15 & 8 & 11 & 1 & - & - & 87 \\
\hline 16. & V-16 & 9 & 8 & 1 & 2 & - & 84 \\
\hline 17. & V-17 & 4 & 10 & 6 & - & - & 78 \\
\hline 18. & V-18 & 7 & 9 & 3 & 1 & - & 82 \\
\hline 19. & V-19 & 4 & 10 & 6 & - & - & 78 \\
\hline 20. & V-20 & 8 & 8 & 4 & - & - & 84 \\
\hline 21. & V-21 & 5 & 9 & 6 & - & - & 86 \\
\hline 22. & V-22 & 9 & 10 & 1 & - & - & 88 \\
\hline 23. & V-23 & 5 & 10 & 4 & 1 & - & 79 \\
\hline & $\Sigma$ & 136 & 231 & 84 & 9 & - & 1874 \\
\hline
\end{tabular}

\begin{tabular}{|l|l|c|c|c|c|}
\hline No. & Kode & $\begin{array}{c}\text { Pre- } \\
\text { test }\end{array}$ & $\begin{array}{c}\text { Post- } \\
\text { Test }\end{array}$ & $\begin{array}{c}\text { Deviasi } \\
\text { (D) }\end{array}$ & $\begin{array}{c}\text { Deviasi } \\
\text { Quadrate } \\
\text { (D })^{2}\end{array}$ \\
\hline 1. & $\mathrm{~V}-1$ & 73 & 75 & 2 & 4 \\
\hline 2. & $\mathrm{~V}-2$ & 67 & 76 & 9 & 81 \\
\hline 3. & $\mathrm{~V}-3$ & 74 & 81 & 7 & 49 \\
\hline 4. & $\mathrm{~V}-4$ & 75 & 82 & 7 & 49 \\
\hline 5. & $\mathrm{~V}-5$ & 74 & 81 & 7 & 49 \\
\hline 6. & $\mathrm{~V}-6$ & 72 & 81 & 9 & 81 \\
\hline 7. & $\mathrm{~V}-7$ & 75 & 77 & 2 & 4 \\
\hline 8. & $\mathrm{~V}-8$ & 74 & 83 & 9 & 81 \\
\hline 9. & $\mathrm{~V}-9$ & 74 & 88 & 7 & 49 \\
\hline 10. & $\mathrm{~V}-10$ & 81 & 83 & 6 & 36 \\
\hline 11. & $\mathrm{~V}-11$ & 77 & 78 & 8 & 64 \\
\hline 12. & $\mathrm{~V}-12$ & 76 & 81 & 5 & 25 \\
\hline 13. & $\mathrm{~V}-13$ & 72 & 80 & 8 & 64 \\
\hline 14. & $\mathrm{~V}-14$ & 71 & 82 & 11 & 121 \\
\hline 15. & $\mathrm{~V}-15$ & 83 & 87 & 4 & 16 \\
\hline 16. & $\mathrm{~V}-16$ & 66 & 84 & 18 & 324 \\
\hline 17. & $\mathrm{~V}-17$ & 69 & 78 & 9 & 81 \\
\hline 18. & $\mathrm{~V}-18$ & 69 & 82 & 13 & 169 \\
\hline 19. & $\mathrm{~V}-19$ & 73 & 78 & 5 & 25 \\
\hline 20. & $\mathrm{~V}-20$ & 73 & 84 & 9 & 81 \\
\hline 21. & $\mathrm{~V}-21$ & 71 & 86 & 15 & 225 \\
\hline 22. & $\mathrm{~V}-22$ & 70 & 88 & 18 & 324 \\
\hline 23. & $\mathrm{~V}-23$ & 73 & 79 & 6 & 36 \\
\hline & $\Sigma$ & 1680 & 1874 & $\mathbf{1 9 4}$ & $\mathbf{2 0 3 8}$ \\
\hline & & & & & \\
\hline
\end{tabular}

Skor rata-rata Deviasi Pre-tes dan Posttes diperoleh dengan membagi jumlah skor deviasi dengan jumlah siswa. Nilai rata-rata deviasi Pre-test dan Post-test dapat dilihat dengan mengikuti rumus di bawah ini:

$$
\begin{aligned}
M X_{1} & =\frac{\sum X_{1}}{N} \\
& =\frac{194}{23}=8.435
\end{aligned}
$$

\section{d) Uji Hipothesis (t-test)}

Pengujian hipotesis adalah proses

\section{c) Deskripsi Data Pre-Test dan Post-Test siswa}

Peneliti menemukan skor Pre-test tertinggi adalah 83, skor terendah adalah 66 dan kisaran skor skor pre-test adalah 17. Sementara skor tertinggi Post-test adalah 88, skor terendah adalah 75 dan kisaran skor posttest adalah 13. Tabel berikut menunjukkan hasil skor pre-test dan post-test siswa secara rinci.

Table 4.4 Scores of Pre-test and Post-test of Questionnaires siswa memutuskan apakah hipotesis alternatif akan diterima atau hipotesis nol akan ditolak. Hipotesis diuji dengan menggunakan rumus ttest. Hipotesis dalam penelitian ini adalah uji $(9.467) \geq$ t-tabel pada taraf signifikansi 0.05 dengan 23 sampel. Dalam menguji hipotesis dan untuk menafsirkan tingkat signifikansi siswa sebelum dan setelah perawatan, peneliti menggunakan model statistik pengujian hipotesis untuk menghitung t-tes sebagai berikut:

$$
\begin{gathered}
\mathrm{t}=\frac{\bar{D}}{\sqrt{\frac{\sum D^{2}-\frac{\left(\sum D\right)^{2}}{N}}{N(N-1)}}}=\frac{194}{\sqrt{\frac{2038-\frac{(194)^{2}}{23}}{23(23-1)}}} \\
=\frac{8.435}{\sqrt{\frac{2038-37636}{506}}}=\frac{8.435}{\sqrt{0.794}}=\frac{8.435}{0.891}=9.467
\end{gathered}
$$

Dalam penelitian ini, sampel data adalah 23 siswa, sehingga tingkat kebebasan (df) yang digunakan 23-1 = 22. Setelah menghitung interpetasi data ditemukan bahwa t-tes $=9.467 \geq$ t-tabel $=1.717$. Dari hasil di 
atas, peneliti menyimpulkan bahwa teknik word category memiliki pengaruh yang signifikan terhadap pemahaman membaca siswa. Oleh karena itu, Hipotesis Alternatif diterima dan Hipotesis Null ditolak

\section{KESIMPULAN}

Berdasakan hasil penelitian disimpulkan bahwa category word sangat effective karena mampu mempengaruhi minat siswa dalam belajar sehingga membuat siswa lebih mudah memahami materi pembelajaran yang disampaikan. Word Category teknik dapat membantu guru dalam mengajar bahasa Inggris yang karena teknik ini melibatkaan siswa bermain samabil belajar sehingga dapat meningakatkan pemahaman kosakata.

\section{SARAN}

Terkait dengan kesimpulan di atas peneliti mengrapkan kepada guru untuk berinovasi dalam mengajar bahasa Inggris terutama untuk mengajar kosakakata dengan cara memilih teknik atau strategi pemebelajaran yang menarik dan menyenangakan sehingga sehingga siswa tidak merasa bosan dikelas atau yang membuat siswa lebih berminat untuk belajar bahasa Inggris dan mempengaruhi minat siswa dalam belajar sehingga membuat siswa akan lebih mudah memahami materi pembelajaran yang disampaikan dan salah satu teknik atau media pengajaran yang tepat yang dapat digunakan guru dalam mengajar menulis adalah Category Word. Dan diharapkan kepada peneliti berikutnya bahwa hasil penelitian ini dapat dijadikan rajukan atau referensi yang ada kaitannya denga kosakata.

\section{DAFTAR PUSTAKA}

Almagarbeh (2015) The Influence of Words Categories on Translating Postgraduate Abstracts in the Field of Evaluation and Measurement at Mu'tah University. EMU. 1 (2) 140154.

Brown, H.D. (2004). Language Assessment Principles and Classroom Practice. (p.20). San Francisco State University: Pearson Education, Inc.

Bloom, B. (1971). Mastery Learning in J, Block (Ed) ,(p.16-17), Mastery Learning: Theory and practice, New York.
Caroline, T. (2005). Practical English Language Teaching: Young Learner Age (p.121) International Publisher.

C.P. Proctor et.al (2011) Improving Comprehension online: Effects of deep Vocabulary Instruction with bilingual and Monolingual FirstGrade $\quad 24 \quad$ (1) 517544.https://link.springer.com/article/1 0.1007/s11145-009-9218-2

Hiebert, H. (2015). Teaching and Learning Vocabulary. (p.3) Mahwah, New Jeresy. London.

Marsland, Bruce. (1998). Lessons from Nothing (p.89). UK: Cambridge University Press.

Kothari, C.R. (2004). Research Methodology: Method \& Technique, (p.16-158) India: New Age International.

Kothari, C.R. (2004). Research Methodology: Method \& Technique, (p.73-74) India: New Age International.

M. Syaeful, R. et.al. (2013). The use of Picture Games to Improve Students' Motivation in Learning Vocabulary. Indonesian English Education Journal, 3 (2). 126-136.

Marsland, Bruce. (1998). Game for childrens (p.16).UK: Cambridge University Press.

Miller, S. (1984). Experimental Design and Statistics $2^{\text {th }}$ Edition, (p.45) New York: Routledge.

Nasution, I.S.P. (2005:43). Learning Vocabulary in another Language (p.43). Cambridge: Cambridge Applied Linguistics.

Nasution : (1977). Teknologi Pendidikan Jakarta (p.87) : BumiAksara.

Nasution : (1996). Bakat dan minatkan. Jakarta (p.96) : BumiAksara.

Sugiyono, (2010). Statistika Untuk Penelitian (p.017). Bandung : Alfabeta.

Sugiyono, (2009). Statistika Untuk Penelitian, (p.23). Bandung : Alfabeta.

Sugiyono. (2014). Metode Penelitian Kuantitatif, Kualitatif dan R\&D, (p.94). Bandung: Alfa beta.

Sarifuddin, M, Terasne, T (2018) Enriching Students, Vocabulary through 
Matching Game at Second-Grade Students of MA Putra Al-Islahuddiny Kediri Lombok Barat in Academic Year 2018/2019. Indonesian Journal Realita. 1 (2), 631-673.

Terasne, T., Sugianto, N., (2019) The use of Think Inside The Box Strategy to Improve Students Vocabulary Mastery at Second-Grade Students of SMPN 4 Praya Barat Daya, Indonesian Journal English Language teaching 4 (5), 312145.

Terasne, T, Tawali, T. Afriani , N,. (2018) The Application of Word Association Game in Improving Students' Vocabulary Mastery at The Second-Grade Student of SMPN 5 Pujut, JISIP, 2 (1), 368-373.

Terasne, T. (2017). The Effectiveness of using Word Map Techinique inTeacing Vocabulary at Thirid-Students of IKIP Mataram in Academic Year 2015/2016. Jo-ELT, 2 (1), 134-142.

Terasne.T (2016). Improving Students' Vocabulray Mastery trough Word Map Techinique inTeacing Vocabulary at Thirid-Students of IKIP Mataram in Academic Year 2014/2015. Jurnal Kependidikan LPPM IKIP Mataram, 2 (1), 134-142.

Thornburry, Scott.(2002). How to Teach Vocabulary (p.32). England: Pearson.

Thornburry, Scott. (2002:56) \& Brown, (2003: 36). Indicators of Vocabulary (p.56). London: Longman Group.

Thornburry, Scott, (2002). Language and vocabulary (p.25) .London: Longman Group

Winkel. L (1996). Lessons from Education (p.96) .UK: Cambridge University Press. 